\title{
Correction to: Digital and Social Media Regulation
}

\author{
Sorin Adam Matei, Franck Rebillard, \\ and Fabrice Rochelandet
}

\section{Correction to:}

S. A. Matei et al. (eds.),

Digital and Social Media Regulation, https://doi.org/10.1007/978-3-030-66759-7

The original version of the book was inadvertently published with incorrect author's name "Fabienne Graff" in Chapters 1, 3, 8 and Front matter, which has now been corrected to "Fabienne Graf". The book has been updated with the changes.

The updated version of the book can be found at https://doi.org/10.1007/978-3-030-66759-7

(C) The Author(s) 2021

S. A. Matei et al. (eds.), Digital and Social Media Regulation, https://doi.org/10.1007/978-3-030-66759-7_10 